\title{
The Extent of the Obligation for the Islamic Banks Working in Jordan in the Disclosure of the Social Responsibility Accounting in Their Financial Statements
}

\author{
Hani Ali Aref Al-Rawashdeh ${ }^{1}$ \& Atef Aqeel Al-Bawab ${ }^{1}$ \\ ${ }^{1}$ Irbid National University, Irbid, Jordan \\ Correspondence: Atef Aqeel Al-Bawab, Irbid National University, Irbid, Jordan. Tel: 962-777-326-901. E-mail: \\ atefbawab@yahoo.com
}

Received: November 7, 2016

Accepted: November 17, $2016 \quad$ Online Published: December 20, 2016

doi:10.5539/ijef.v9n1p180

URL: http://dx.doi.org/10.5539/ijef.v9n1p180

\begin{abstract}
This study aims at identifying the commitment of the Islamic banks working in Jordan to social responsibility as well as the indenturing of the accounting standards to the Islamic banks to disclose their social responsibility in their financial statements. The population of the study consisted of the managers and assistants of the Islamic banks' branches working in Jordan or their deputies as a random sample was chosen from said population. (35) Questionnaires were distributed from which (30) questionnaires were recollected rating at (86\%) of the study sample. The most important results of the study were that the Islamic banks perform their social responsibilities towards the local community in which they work in addition to the fact that the Islamic accounting standards care for accounting disclosure for the social dimension in the financial statements of the Jordanian Islamic banks in a periodical and organized manner. The study presented several recommendations such as the necessity of embedding social information in the basic financial statements and revealing the amounts of Zakat and donations in separate items in the income statement, the granted goodwill loans statement and due Zakat amounts.
\end{abstract}

Keywords: the Islamic banks, social responsibility accounting, disclosure

\section{Introduction}

The economic thinking reflected upon the accounting thinking in terms of attending social responsibility. In its report published in 1973, The American Accountants Association stated that of the objectives of financial statements is preparing a report about social activities. Many studies emphasized the importance of disclosing the fulfillment of the company to its social liabilities and its influence in the investors' decisions (Abu-Samrah, 2009, pp. 18, 24).

Recently, the debate rised about the social responsibility of different types of companies and the non - restriction of performance evaluation to the economic aspect and the degree of profit realization of the company, but we should also consider the attention of the company to the social aspect and making social responsibility one of the basic responsibilities of the company. Seldom (1923) is considered the first to refer to the company's interest in the social responsibility when performing its different tasks. (Jarbou, 2007, p. 240). The American Accountants Association (AAA) referred to the following:

The accounting information is the basic means to lessen the uncertainty among the external users in addition to being basic means to report practice. In order for the financial reports to achieve their purposes and to be of maximum benefit, the vocational organizations stipulated the provision of disclosure and clarity as a fundamental method to communicate accounting information to different beneficiaries.

The accounting standard issued by the accounting and auditing organization for Islamic financial institutions declared that those standards did not ignore the importance of disclosing the social responsibilities and this is clear in the financial accounting standard No. (1) For the year 1993 under the title: "The general presentation and disclosure in the financial statements of the Islamic banks and financial institutions", that banks have to prepare a number of financial statements like: (the accounting and auditing standard and control of the Islamic financial institutions - standard (1)).

This research concentrates on identifying the concept of social responsibility and the interest of the accounting 
standards issued by the association of accounting and auditing for the Islamic financial institutions to the necessity of the accounting disclosure about the social dimension and the commitment of the Jordanian Islamic banks to the accounting disclosure about the social responsibility in the financial statements.

In this study it was presented the study problem, significance and literature review, while the second section we offered the theoretical framework regarding accounting responsibility and Islamic banks, either in Section III has been analyzing and testing hypotheses of the study and display their findings and make recommendations.

\subsection{Problem of the Study}

Organizations are required to present and disclose the information about their engagement in society service. Therefore, the social performance of the organization is no less important than its economic performance as it accomplishes its job by utilizing the economic resources of the society, so it has to compensate the society for those resources by providing comprehensive social services as part of its interaction with the social environment. The disavowal of the organization to its social responsibilities has negative reflection on both the society and organization because the economic success of the organization without realizing social success will impose high costs on the long run and will affect its mental image. Based on the formerly stated, the problem of the study can be summarized in the following questions:

1) Are the Islamic banks working in Jordan interested in social responsibility?

2) Do the Islamic accounting standards care for accounting disclosure about the social dimension in the financial statements of the Islamic banks working in Jordan?

3) Do the Islamic banks working in Jordan care for disclosing social responsibility in their financial statements?

\subsection{Importance of the Study}

The importance of the study stems from the extent to which the Islamic banks working in Jordan care for the local society to have a distinctive role in the banking arena, to adopt the attention to social responsibility and not to focus on realizing high profits and ignore the basic objectives of the establishment of Islamic banks through their adherence to the principle of our honorable religion which made man the most noble purpose of life. Here comes the importance of the study in shedding light on the concept and fields of social responsibility and the attitude of the financial accounting standard No. (1) which is concerned with "The general presentation and disclosure in the financial statements of the Islamic banks and financial institutions" and identifying the realization of the Islamic banks to the importance of holding social responsibility and their participation in the different social programs as well as projecting light on their commitment to the accounting disclosure about social responsibility in the financial statements they issue.

\subsection{Objectives of the Study}

This study aims at:

1) Identifying the commitment of the Islamic banks working in Jordan to social responsibility.

2) Identifying the obligation of the accounting standards to the Islamic banks working in Jordan to disclose their social responsibility in their financial statements.

3) Identifying the disclosure of the Islamic banks working in Jordan about the information of their social responsibility in their annual reports.

\section{Literature Review}

Here we try to preview a number of studies which are close and relevant to the subject of the present study as follows:

1) Al-Zeyoud (2013) conducted a study that aimed at showing the commitment of the banks working in Jordan to their social responsibility towards the external and internal community of their workers. The monetary contributions of the social domains were analyzed as an absolute value as well as a ratio of the net profits and the extension of the bank's branches outside the capital to contribute in development and client services. The study's hypotheses were applied on 15 banks in the period between 2008 and 2010. The results showed that the banks are holding their responsibilities in relation to the local community as part of their policies and plans to achieve sustainable development. As for the internal dimension, there was underacting concerning the amounts spent on the workers in addition to short attention to the training and development of workers. The researcher recommends the necessity of increasing the level of awareness to the concept of social responsibility and providing more incentives to the banks which adopt this concept and to have clear and specific standards to give 
support to the beneficiaries.

2) The study of Abul-hassan (2010) aimed to reveal the presence of any contradiction between the social activities of the companies in the annual reports of the Islamic banks and the corporate social responsibility index which was developed according to the Islamic ethics framework. To achieve the objectives of the study, the researcher analyzed the contents of the annual reports of seven Islamic banks in the Indonesian capital, Jakarta, to measure the size of social responsibility exposure of the companies. The results showed that one bank out of seven Islamic banks was above average concerning corporate social responsibility. In addition, the corporate social responsibility was not a source of anxiety to the majority of the banks under study.

3) New Jordan Center (2009) conducted a study which aimed at identifying view orientations in the Jordanian company managements toward their social responsibility and whether or not it was incorporated within their strategies and how companies understand their social responsibilities. The study also attempted to spot the stimulating factors of practicing social responsibility. To achieve the objectives of the study, a questionnaire was designed containing questions which include the different axes related to its goals. The study produced several results concerning the comprehension of executive managers and company managements to social responsibility. The study revealed that $71.3 \%$ of the studied subjects believed that social responsibility means the commitment of companies to the applicable laws. 57\% stated that its means the improvement of the internal structure of the company while $53.8 \%$ said it means improving customer services. 50.7\% stated that it means the service of the local society as a whole. $43.9 \%$ connected social responsibility to charity and donations.

4) Fneir (2009) arranged a study in Libya to point out the effect of social responsibility disclosure on the decision of granting loans and credit facilities by banks. The study results showed that disclosing the responsibilities of the decisions of granting loans and credit facilities among banks in Libya has positive effect, but the results revealed the existence of shortage in the disclosure of financial statements which led to lowering the role of the Libyan banks in realizing social responsibility.

\subsection{The Distinction of This Study Over the Previous Studies}

This study came to state the disclosure of the Jordanian Islamic banks in their financial statements of the social responsibility they carry to serve the local society and contribute in its development like the other studies which aimed at showing the opinions of managements in the social responsibility shouldered by their financial institutions towards the local community and to show if there were any contradiction between the social activities of companies in the annual reports of the Islamic banks, and the index of exposing the companies social responsibility which was developed depending on the Islamic ethics framework.

\subsection{The Study Hypotheses}

Based on the study's problem and questions and the previous studies, the following hypotheses were built:

\section{First: The first hypothesis states:}

HO1: The Islamic banks working in Jordan do not care for social responsibility.

\section{Second: The second hypothesis states:}

HO2: The accounting standards do not care for accounting disclosure about the social dimension in the financial statements of the Islamic banks working in Jordan.

\section{Third: The third hypothesis states:}

HO3: The Islamic banks working in Jordan do not disclose social responsibility in their annual reports.

\subsection{The Theoretical Framework}

\subsubsection{The Origination of Islamic Banks}

Many consider Islamic banking as a new phenomenon while they do not realize that it is an integral part of the Islamic economic system within the Islamic creed.

Therefore, one who traces the history and genesis of Islamic banks will realize the importance of those banks which made them prove themselves day after day and spread fast. In the Islamic world, more courageous and stronger positive attempts appeared and were represented in:

Saving banks "Egypt" in (1963) followed by another attempt in "Egypt" which was Nasser social bank in (1971) then Islamic bank for Development in Saudi Arabia in (1974) then Dubai Islamic Bank in (1975) then Faisal bank in Sudan in (1977) then the Kuwaiti Financing bank in (1977) then the Faisal Islamic bank "Egypt" in (1977) then the "Jordanian" Islamic bank for finance and investment in (1978). 


\subsubsection{The concept of Islamic Banks}

It is an institution which performs banking works on the basis of Islamic legislation (Sharia) and its jurisprudential (Fiqh) principles.

It is a banking financial institution to collect and employ money in the frame of Islamic legislation to realize social Islamic solidarity, just distribution and putting the money on the Islamic course.

\subsubsection{Characteristics of Islamic Banks}

There are several basic characteristics which distinguish the Islamic bank:

1) Full commitment to the Islamic rules in all its banking transactions.

2) Not dealing with bank interests whether taking or giving, directly or indirectly, as it is forbidden usury.

3) Establishing the principle of profit or loss share through mediating the bank between money owners and finance applicants without putting the risk on one party alone.

4) Creating real economic and social development in society.

5) Establishing the principle of social solidarity, not only by collecting and spending Zakat in its legal outlets but also through the attempt of achieving justice in distributing the revenues of the invested property and maximizing the social revenue of investment.

\subsection{Objectives of Islamic Banks}

There are three objectives of the Islamic banks

\subsubsection{The Developmental Objective}

Islamic banks contribute effectively in the realization of economic and social development. Their banking transactions agree with the legal controls through a distinctive developmental pattern which achieves progress, justice and constancy by means of:

- Seeking to attract the Islamic capital and increasing the collective self-dependence among the Islamic countries.

- The reemployment of Islamic accounts inside the basic products and services.

- Promoting the investment projects in all the legal economic activities.

\subsubsection{The Investing Objective}

The investment goals of the Islamic bank are the following:

- Achieving high operational employment to the production factors in society.

- Improving the economic performance of the organizations supervised by the bank or the other "terminating the markets"

- Promoting the projects of the bank or other parties.

- Realizing an appropriate level of stability in the prices of goods and services dealt within the markets to suit the level of income.

- Achieving justice in distributing the operational outcome of the investment contributing in the justful distribution of proceeds among the production factors which share in the production process.

\subsubsection{The Social Objective}

This appears through the contribution of Islamic banks in achieving social justice by choosing the projects which participate in improving the distribution of income, granting goodwill loans or establishing social projects using several methods such as:

- Developing the confidence of citizens in the Islamic economic system.

- $\quad$ Fighting usury and monopoly.

- $\quad$ Achieving just distribution of fortune.

\subsection{The Concept of Accounting Disclosure}

Accounting disclosure is the stage where accountants can express their efforts in providing accounting information.

It is of the familiar accounting principles and the accountants agreed on adopting this principle when preparing 
the published financial statements which helps the people concerned from outside the projects to take the right decisions in the light of the information they get from those statements.

The American Institute of Certified Public Accountants defined it as "The presentation of the financial statements according to the agreed accounting principles form and is related to the form and classification of the information in the financial statements and the meanings of their terminology".

Many writers talked about the concept and importance of disclosure. Hendrikson defined it as presenting the important information for investors and debtors and other beneficiaries in a manner that allows to predict the capacity of the project to realize profits in the future and the ability to settle its obligations.

Choi defined it as announcing the economic information related to the project whether quantitative or else to help the investor to take decisions and reduce the state of uncertainty concerning the future economic events.

\subsection{The Concept of Social Responsibility and Its Accounting}

The social responsibility of organizations stems from their responsibility towards the external environment (Jawad, 2000, p. 61; Al-Amiri \& Al-Ghalibi, 2008, p. 48). In its comprehension concept, social responsibility includes the commitment to realize balance among different parties which are connected with the interests and needs of the external environment and society (Al-Tweijri, 1988, p. 26; Al-Hamadeen, 2002).

Researchers produced many definitions to the social responsibility. Drucker stated that social responsibility is the commitment of the establishment towards the society it works in (Drucker, 1977, p. 584). As viewed by Holmos, it represents the society through contributing in a large number of social activities like fighting poverty, improving health services, fighting pollution, creating job opportunities and solving the problems of housing and transportation (Homlos, 1985, p. 435).

The world business council for sustainable development defined social responsibility as the constant obligation by the business companies to act morally and to contribute in achieving economic development and improving the living conditions of the working power and their families and the local society as a whole.

Social responsibility was also defined as the moral responsibility of the organization towards the stakeholders which will be directly or indirectly affected by the actions of the organization (Jones, 2001, p. 153). This definition shows that ethics have a big role in social responsibility.

Pride defines social responsibility as the admission that business activities have influence on the society, and considering that influence when taking business decisions (Pride, 2005, p. 42).

Williamas states that it is the commitment of business sector to following up with the policies and works that constrain society (Williamas, 2002, p. 42)

Through my own point of view, the concept of social responsibility differed, but despite this difference, there is a common divisor among those concepts which is the fact that companies should not be interested only in profit but participate in social actions that have good influence on society as well, This happened after companies and private sector corporations realized that they were part of this society and that their activities are viewed by many people, so they have now to expand their activities to include social domains.

\subsection{Islamic Banks and Social Responsibility}

The Islamic banking system is built on the Islamic creed. Its principles are based on the Islamic economy methodology which represents part of the inclusive legislation in order to create balance between the individual and society interests (Al-Mughrabi, 2006, p. 83).

The Islamic banking sector is the most important and the fastest developed in the world as it contains more than (400 financial institutions and manages more than one trillion U.S. Dollars of assets (the website of the Islamic bank of Dubai).

The definitions related to Islamic banks are multiple, from which are:

1) The Islamic bank is "a banking financial institution to collect money and employ it in building the society of Islamic solidarity, achieving justice in distribution and putting the money in the Islamic course" (Al-Najjar, 1982, p. 163).

2) The Islamic bank is "a banking institution which harmonizes, in all its transactions and investing activities and management of its actions with the Islamic legislations and its purposes, and also with the internal and external objectives of the Islamic society" (Ershied, 2001, p. 14).

3) The Islamic bank is "a banking financial institution which collects the financial supplies and employs them 
in areas that serve the national economy according to legal restrictions to realize profit. It has a human message with developmental and social dimension that aims at providing financial products that have legal integrity" (Obadah, 2008, p. 29).

4) The Islamic bank is "a financial institution which collects property and invests it and develops it for the best interest of participants and for the reconstruction of the Islamic society and achieving Islamic cooperation according to the legal principles" (Fattahi, 2009, p.70).

According to my own point of view and concept about the Islamic reference of the Islamic banks and the role of money in economic social life, the role of banks is not restricted to realizing the interest of money owners or just adhering to the rules of right and wrong but important pillar is added to all that, which is considering the rights of society in this property.

\section{Methodology of the Study}

The analytical descriptive approach was adopted. The previous studies in the field of social responsibility were viewed to identify its concept and dimensions. The Islamic accounting standards were also looked into to verify their consideration to the accounting disclosure for the social dimension.

\subsection{The Study Population and Sample}

Starting from the concept and objectives of the Islamic banks and the necessity of performing their social role, the Islamic banks sector was chosen to be the locale of this study.

The study population consisted of all the Islamic banks working in Jordan whereby (35) questionnaires were distributed on the managers of head offices and branches and assistant mangers or their deputies to recognize the strength and weakness points in those banks and their extent of disclosure to social responsibility in their financial statements. (30) Questionnaires, at the rate of (86\%), were recollected from the study sample. The number of Islamic banks working in Jordan are four banks: (The Arab Islamic bank of Jordan/Jordan Islamic bank/Jordan-Dubai Islamic bank/Al-Rajihi bank).

\subsection{The Statistical Methods Used}

The statistical program (SPSS) was used to conduct the necessary tests which were the following:

1) Chronbach's Alpha to verify the liability of the study tool.

2) The frequencies, mean standard deviations and percentages of the study sample and tool.

3) T-test to check the differences among the samples.

\subsection{The Study Tool}

To reach at the expected results in this study, a questionnaire was prepared about the literature and previous studies which were conducted on the largest professional organizations concerned with social responsibility.

(35) Questionnaires were distributed on the managers and their assistants and deputies in the Jordanian Islamic banks. (30) Questionnaires were retrieved which equals $(85 \%)$ of the total questionnaires while Likert scale quintet was used to determine the importance degree of each clause in the questionnaires. As for the study tool, the internal reliability was calculated for the study tool's axes as well as the overall reliability by using Chronbach's Alpha reliability coefficient by means of (Test and Retest) where the reliability coefficient of the tool's axes ranged between $(0.79)$ and $(0.87)$ and the overall reliability coefficient of the tool was $(0.83)$ which is an acceptable rate in this type of studies. Look at Table 1.

Table 1. Charonbach's Alpha coefficients to verify the reliability of the study tool

\begin{tabular}{ll}
\hline Variable & Chronbach's Alpha \\
\hline The Jordanian Islamic bank's interest in social responsibility & 0.87 \\
The attention of the Islamic accounting standards to the accounting disclosure about the social dimension in the & 0.83 \\
financial statements of the Islamic banks & 0.79 \\
The commitment of the Islamic banks to the disclosure of the social responsibility in their financial statements & 0.83 \\
Overall reliability & \\
\hline
\end{tabular}

\section{Analyzing Data and Answering the Study Questions}

\subsection{The Study Results}

First question: Is there an effect of the attention of the Islamic banks working in Jordan to social responsibility? 
Table 2. A summary of the sample members' views about the attention degree of the Islamic banks working in Jordan to social responsibility

\begin{tabular}{llcc}
\hline No. & Clause & Arithmetic mean & Standard deviation \\
\hline 2. & The Islamic banks working in Jordan care for social responsibility towards the & 3.92 & 0.79 \\
& & & 0.85 \\
3. & The Islamic banks working in Jordan care for social responsibility towards the workers & 4 & 0.9 \\
4. Social responsibility is one of the bank's priorities & 4.42 & 0.66 \\
5. The fulfillment of the obligations related to social responsibility is one of the bank's & 4.42 & 0.49 \\
$\quad$ objectives & 4.67 & 0.74 \\
1. The Islamic banks working in Jordan care for social responsibility towards the society & 4.28 & \\
General mean
\end{tabular}

The former table states that the arithmetic means ranged between (3.92-4.67), and that the highest arithmetic mean was for item No. (1) Which stated "The Islamic banks working in Jordan care for social responsibility towards the society" with an arithmetic mean of (4.67) and a standard deviation of (0.49). The least arithmetic mean was for item No. (2) Which stated "The Islamic banks working in Jordan care for social responsibility towards the environment" with an arithmetic mean of (3.74) and a standard deviation of (0.74). The results refer to the rising level of the Jordanian Islamic banks' attention to social responsibility and this can be attributed the high involvement of the Islamic banks working in Jordan with the local businessmen and investors.

First Hypothesis: There is no statistically significant effect at $(a=0.05)$ for the attention of the Islamic banks working in Jordan to social responsibility.

Table 3. The arithmetic means, standard deviations and T-value of the sample members answer to the issue of the attention of the Islamic banks working in Jordan to social responsibility

\begin{tabular}{llcccc}
\hline The attention of the Islamic banks working & Arithmetic mean & Standard deviation & Degrees of freedom & T-value & Significance level \\
\cline { 2 - 6 } in Jordan to social responsibility & 21.4 & 1.072 & 29 & 4.325 & 0.000 \\
\hline
\end{tabular}

Viewing the former table, we find that there is a statistically significant effect at Alpha (0.05) for the attention of the Islamic banks working in Jordan to social responsibility as the calculated significance level was less than the significance level Alpha (0.05) and consequently the acceptance of the alternative hypothesis and the rejection of the null hypothesis and the arithmetic mean which reached at (21.4) indicates the strength and positivity of the relationship.

Second question: Is there an effect of the care of the Islamic accounting standards for the accounting disclosure about social dimension in the financial statements of the Islamic banks working in Jordan?

Table 4. A summary of the sample members views about the attention of the Islamic accounting standards to the accounting disclosure about the social dimension in the financial statements of the Islamic banks working in Jordan

\begin{tabular}{llcc}
\hline No. & Clause & Arithmetic mean & Standard deviation \\
\hline 3. & The application of disclosure standards about the social dimension helps banks \\
managements to rationalize decision making & 3.75 & 0.75 \\
2. $\quad \begin{array}{l}\text { The application of disclosure standards about the social dimension helps to } \\
\text { increase the quality of the accounting information in the financial statements }\end{array}$ & 4 & 0.60 \\
1. $\quad$ The Islamic accounting disclosure standard obliged the Islamic banks working & 4.25 & 0.45 \\
$\quad$ in Jordan to disclose social responsibility in their statements & 4.33 & 0.49 \\
4. The commitment to Islamic accounting standards facilitates account auditing & 4.5 & 0.52 \\
5. The commitment to Islamic accounting standards leads to the preparation of & & $\mathbf{0 . 5 6}$ \\
financial statements which agree with the international accounting standards & $\mathbf{4 . 1 6}$ & \\
General mean
\end{tabular}

The former table indicates that the arithmetic means ranged between $(3.75-4.50)$, and that the highest arithmetic mean was for item No. (5) Which stated "The commitment to Islamic accounting standards leads to the preparation of financial statements which agree with the international accounting standards" with an arithmetic mean of (4.50) and a standard deviation of (0.520). The least arithmetic mean was for item No. (4) which stated "The application of disclosure standards about the social dimension helps banks managements to rationalize 
decision making" with an arithmetic mean of (3.75) and a standard deviation of (0.754), while the general arithmetic mean was (4.16) with a standard deviation of (0.56). The previous results point out the rise of the degree of attention of the Islamic accounting standards to the accounting disclosure about the social dimension in the financial statements of the Jordanian Islamic banks which can be attributed to the commitment of the Jordanian Islamic banks to the principles of transparency and trust, in addition to the rise of the public expectations from those banks that their role is not restricted to only facilitating the financial transactions but also in contributing in the social aspects of the surrounding local society.

Second hypothesis: there is no statistically significant effect at $(\mathbf{a}=\mathbf{0 . 0 5})$ of the attention of the Islamic accounting standards to the accounting disclosure about the social dimension in the financial statements of the Islamic banks.

Table 5. The arithmetic means, standard deviations and T-value of the study sample members answer to the issue of the attention of the Islamic accounting standards to the accounting disclosure about social dimension in the financial statements of the Islamic banks

\begin{tabular}{lcccccc}
\hline $\begin{array}{l}\text { The attention of the Islamic accounting standards to the } \\
\text { accounting disclosure about social dimension in the financial } \\
\text { statements of the Islamic banks working in Jordan }\end{array}$ & $\begin{array}{c}\text { arithmetic } \\
\text { means }\end{array}$ & $\begin{array}{c}\text { standard } \\
\text { deviation }\end{array}$ & $\begin{array}{c}\text { degrees of } \\
\text { freedom }\end{array}$ & $\begin{array}{c}\text { T-value } \\
\text { significance } \\
\text { level }\end{array}$ \\
\hline
\end{tabular}

Viewing the former table, we find that there is a statistically significant effect at Alpha (0.05) of the attention of the Islamic accounting standards to the accounting disclosure about the social dimension in the financial statements of the Islamic banks working in Jordan as the calculated significance level was less than the significance level Alpha (0.05) and consequently the acceptance of the alternative hypothesis and the rejection of the null hypothesis. The arithmetic mean which reached at (21.4) indicates the strength and positivity of the relationship.

Third question: What is the degree of the Islamic banks working in Jordan commitment to the disclosure of social responsibility in their financial statements?

Table 6. A summary of the sample members views about the degree of commitment of the Islamic banks working in Jordan to the disclosure of social responsibility in their annual reports

\begin{tabular}{lcc}
\hline No. clause & arithmetic mean & standard deviation \\
\hline 2. The Islamic banks working in Jordan disclose the social activities related to the & 3.83 & 0.57 \\
environment & 3.92 & 0.66 \\
3. The Islamic banks working in Jordan disclose the social activities related to the workers & 4.08 & 0.90 \\
4. The Islamic banks working in Jordan disclose the financial information related to the social & & 0.86 \\
dimension in their financial statements & 4.33 & 0.88 \\
1. The Islamic banks working in Jordan disclose the social activities related to the society & 4.08 \\
5. The Islamic banks working in Jordan disclose their obligations related to the social & 0.78 \\
dimension through their financial and non-financial reports & & \\
General mean
\end{tabular}

The former table states that the arithmetic means ranged between (3.83-4.33), and that the highest arithmetic mean was for item No. (5) Which stated "The Islamic banks working in Jordan disclose their obligations related to the social dimension through their financial and non-financial reports" with an arithmetic mean of (4.33) and a standard deviation of (0.88), while the least arithmetic mean was for item No. (2) Which stated "The Islamic banks working in Jordan disclose the social activities related to the environment" with an arithmetic mean of (3.83) and a standard deviation of (0.57). The general arithmetic mean was (4.08) with a standard deviation of (0.78). The previous results indicate the high level of the Islamic banks commitment to the disclosure of the social responsibility in their annual reports. This can be attributed to the commitment of the Jordanian Islamic banks to the internal and external social responsibility dimensions which were determined by the European Commission and which should be recognized by all commercial companies as they are related to human rights.

Second hypothesis: There is no statistically significant effect at $(\mathrm{a}=0.05)$ of the commitment of the Islamic banks working in Jordan standards to the disclosure of the social responsibility in their financial statements. 
Table 7. The arithmetic means, standard deviations and T-value of the study sample members answer to the issue of the Islamic banks commitment to the disclosure of social responsibility in their financial statements

\begin{tabular}{|c|c|c|c|c|c|}
\hline \multirow{2}{*}{$\begin{array}{l}\text { The commitment of the Islamic banks working } \\
\text { in Jordan to the disclosure of social } \\
\text { responsibility in their financial statements }\end{array}$} & $\begin{array}{c}\text { arithmetic } \\
\text { mean }\end{array}$ & $\begin{array}{c}\text { standard } \\
\text { deviation }\end{array}$ & $\begin{array}{c}\text { degrees of } \\
\text { freedom }\end{array}$ & T-value & $\begin{array}{c}\text { significance } \\
\text { level }\end{array}$ \\
\hline & 20.4 & 1.044 & 29 & 4.987 & 0.001 \\
\hline
\end{tabular}

The previous table shows that there is a statistically significant effect at Alpha (0.05) of the commitment of the Islamic banks of Jordan to the disclosure of social responsibility in their financial statements where the calculated significance level was less than the significance level Alpha (0.05) and consequently the acceptance of the alternative hypothesis and the rejection of the null hypothesis. The arithmetic mean which reached at (21.4) refers to the strength and positivity of the relationship.

\section{Conclusions}

The Islamic banks of Jordan perform their social responsibility towards the local society under which they work, i.e. there is attention by Islamic banks to social responsibility and this indicates the participation of Islamic banks with the local society which appears from the donation and (Zakat) presented to the individuals.

Also The Islamic accounting standards care for the accounting disclosure about the social dimension in the financial statements of the Islamic banks of Jordan and this point out that the Islamic accounting standards considered the social responsibility of the Islamic banks towards the societies they work in.

And The Islamic banks of Jordan are committed to the disclosure of social responsibility in their financial statements periodically and orderly and this appears in the disclosure attached to the financial statements of those banks.

\section{Recommendations}

The researchers recommends several issues:

1) The necessity of merging social information in the main financial statements and stating the amounts of Zakat and donations paid in separate items in the income statement and clarifying the due Zakat amounts in separate items in the final budget and not to restrict their disclosure in the explanations attached to the statements.

2) The necessity of awareness and persuasion of the administrative cadres in the Islamic banks of the importance of preserving and protecting the environment as a social responsibility priority of Islamic banks to adhere the Islamic values through preparing specialized awareness programs in this domain.

3) Enhancing the concept of social responsibility which will help to direct the exploitation of available resources to serve the economic and social demands of the Islamic banks.

4) Conducting more researches about the means of enhancing social responsibility and its accounting as an effective means to help the organizations to survive and realize a competitive advantage under competition.

\section{References}

Abdul-hassan, S. S. H. (2010). Exploring Coporate social responsibility and accountability: Evidence from an Emerging. Managerial Auditing Journal, 18(6/7), 538-548.

Abu, S., \& Hamed, A. S. (2009). Disclosure detainers about social responsibility in the reports of the general shareholding companies listed in Palestine stock market through the perspective of auditors and company managers. Master thesis, Islamic University, Faculty of Commerce, Gazza, Palestine.

Al-Hmadeen, R. (2002). Social Responsibility Accounting in Jordan Institutions: A Field Study, Unpublished MA thesis, Al Al-Beit university, Mafraq, Jordan.

Al-Mughrabi, Abdul-Hameed, \& Abdul-Fattah. (2004). The strategic management in the Islamic banks (1st ed.). The Islamic institute for research and training, the Islamic bank for development, Jeddah, Riyadh.

Al-Najjar, A. (1982). Islamic Banks. Journal of contemporary Muslim, (24).

Al-Tuweijri, M. (n. d.). social responsibility in the private sector in the Kingdom of Saudi Arabia. Arab Journal of Management, (4), 26-38.

Al-Ziyoud, A. T. (2013). Social responsibility of banks working in Jordan (1st ed.). Scientific Research Deanship, 40(1).

Drunker, P. F. (1977). An Introductory View of Management. USA: Harpers college press. 
Ershaiyed, M. A. (2001). The inclusive in the Islamic banks transactions and operations (1st ed.). Dar Al-nafes for publishing and distribution, Amman, Jordan.

Fatahi, Ayman Abdul-Rahman (2009). Islamic banks and financial institutions (1st ed.). Dar Al-Bashaier publications, Damascus, Syria.

Holmes, S. (1985). Cororate-Social: performance and present Areas of Commitment. Academy of Management Journal, 20.

Jarbou, Y. M. (2007). The extent of applying measurement and disclosure in the accounting of social responsibility in the financial statements in the companies of Gazza strip. Islamic University Journal, Human Studies Series, 15(1).

Jones, G. R. (2001). Organizational Theory. USA: perntic Hall.

New Jordan Center for studies. (2009). View orientation in the Jordanian companies managements towards social responsibility of companies. Prepared by Hani Al-Horani and Mai Al-Taher, Dar Sindibad for publishing and distribution, Amman.

Pride, W. M., Hughes, R. J., \& Kapoor, J. R. (2005). Business. Houghton Mifflin Company, USA.

The international union of Islamic banks. (1977). The agreement: Establishing the international union of Islamic banks. New Egypt, Cairo, 1977, p. 10.

Ubadah, I. A. (2008). Performance indicators in the Islamic banks (1st ed.). Dar Al-Nafaes for publishing and distribution, Jordan.

Willams, C. (2002). Management. USA: South-Western Collage publishing.

\section{Copyrights}

Copyright for this article is retained by the author(s), with first publication rights granted to the journal.

This is an open-access article distributed under the terms and conditions of the Creative Commons Attribution license (http://creativecommons.org/licenses/by/4.0/). 